\title{
Apoptosis, cytokine and chemokine induction by non-structural 1 (NS1) proteins encoded by different influenza subtypes
}

\author{
WY Lam ${ }^{1}$ Apple CM Yeung ${ }^{1}$ and Paul KS Chan ${ }^{1,2^{*}}$
}

\begin{abstract}
Background: Influenza pandemic remains a serious threat to human health. Viruses of avian origin, H5N1, H7N7 and H9N2, have repeatedly crossed the species barrier to infect humans. Recently, a novel strain originated from swine has evolved to a pandemic. This study aims at improving our understanding on the pathogenic mechanism of influenza viruses, in particular the role of non-structural (NS1) protein in inducing pro-inflammatory and apoptotic responses.

Methods: Human lung epithelial cells (NCl-H292) was used as an in-vitro model to study cytokine/chemokine production and apoptosis induced by transfection of NS1 mRNA encoded by seven infleunza subtypes (seasonal and pandemic $\mathrm{H1}, \mathrm{H} 2, \mathrm{H} 3, \mathrm{H} 5, \mathrm{H} 7$, and $\mathrm{H} 9$ ), respectively.

Results: The results showed that CXCL-10/IP10 was most prominently induced (> 1000 folds) and IL-6 was slightly induced ( $<10$ folds) by all subtypes. A subtype-dependent pattern was observed for CCL-2/MCP-1, CCL3/MIP-1 $\alpha$, CCL-5/RANTES and CXCL-9/MIG; where induction by H5N1 was much higher than all other subtypes examined. All subtypes induced a similar temporal profile of apoptosis following transfection. The level of apoptosis induced by H5N1 was remarkably higher than all others. The cytokine/chemokine and apoptosis inducing ability of the 2009 pandemic H1N1 was similar to previous seasonal strains.

Conclusions: In conclusion, the NS1 protein encoded by H5N1 carries a remarkably different property as compared to other avian and human subtypes, and is one of the keys to its high pathogenicity. NCl-H292 cells system proves to be a good in-vitro model to delineate the property of NS1 proteins.
\end{abstract}

Keywords: Pandemic influenza, Avian influenza, NS1, Inflammation, Hypercytokinemia, Apoptosis, Pathogenesis

\section{Background}

Influenza A viruses are major animal and human pathogens with potential to cause pandemics. Avian subtypes $\mathrm{H} 5 \mathrm{~N} 1, \mathrm{H} 7 \mathrm{~N} 7$ and $\mathrm{H} 9 \mathrm{~N} 2$ have repeatedly crossed the species barrier to infect humans [1-8]. Since 2003, there have been repeated outbreaks of $\mathrm{H} 5 \mathrm{~N} 1$ in poultries and sporadic human infections associated with high mortality $[8,9]$. The recently emerged swine-origin influenza A virus (2009 pandemic H1N1 influenza virus - 2009 pdmH1N1) has spread globally within a few months

\footnotetext{
* Correspondence: paulkschan@cuhk.edu.hk

'Department of Microbiology, Faculty of Medicine. The Chinese University of Hong Kong, 1/F Clinical Sciences Building, Prince of Wales Hospital, Shatin, New Territories, Hong Kong Special Administration Region of the People's Republic of China

Full list of author information is available at the end of the article
}

following the initial detection in Mexico and United States in April 2009, resulting in another influenza pandemic as declared by the World Health Organization (WHO) on June 112009 [10]. Although most of the infections are associated with a mild, self-limiting influenza-like illness; the fact that some severe and even fatal outcomes have been observed in individuals without underlying medical conditions poses concerns regarding the pathogenesis of 2009 pdmH1N1 [11,12].

Previous data on human infection with avian influenza virus indicate that cytokine storm is a key mediator, as well as a predictor, for adverse clinical outcomes; especially the haemophagocytic syndrome commonly seen in severe human influenza A H5N1 infections [4,13-16] The preferential infection of deeper lung cells and the 
prompt induction of apoptosis may also explain the rapid deterioration in lung function [17]. In short, influenza infection can go through a direct pathogenic pathway by inducing apoptosis, and hence cell death and loss of critical function; and alternatively or most probably at the same time through an indirect pathogenic pathway by inducing excessive cytokine/chemokine production from the infected cells. The state of hypercytokinaemia will then trigger adverse consequences such as haemophagocytic syndrome [18].

The virulence of influenza A virus is a polygenic trait. Multiple molecular interactions are involved in determining the outcome of an influenza infection in certain host species [19-28]. The genome of influenza virus is segmented, consisting of eight single-stranded, negative sense RNA molecules, which encode eleven proteins [29]. These are polymerase basic protein 1 (PB1), PB1F2 protein, polymerase basic protein 2 (PB2), polymerase acidic protein (PA), hemagglutinin (HA), nucleoprotein (NP), neuraminidase (NA), matrix protein 1 (M1), matrix protein 2 (M2), non-structural protein 1 (NS1) and non-structural protein 2 (NS2) [17]. This study focused on NS1 protein which carries multiple functions including the control of temporal synthesis of viral-specific mRNA and viral genomic RNAs [30,31], and interaction with the cellular protein phosphatidylinositol-3kinase (PI3-kinase) [32-34]; which may cause a delay in virus-induced apoptosis [35]. NS1 protein also has an ability to circumvent the host cell antiviral responses by blocking the activation of RNaseL [36], limiting the induction of interferon (IFN)- $\beta$ [37-39], interacting with the cellular protein retinoic acid-inducible gene product I (RIG-I) [40-42], blocking host cell mRNA polyadenylation $[43,44]$, blocking the double-stranded-RNA-activated protein kinase (PKR)-mediated inhibition of protein synthesis $[31,45]$, and interacting with cellular PDZ-binding proteins [46]. Furthermore, it has been shown that NS1 protein prevents the maturation of human primary dendritic cells, thereby limiting host $\mathrm{T}$ cell activation [47].

To improve our understanding on the pathogenic mechanism of the newly emerged pandemic strain as well as for influenza viruses in general, we set on this study to examine the property of NS1 proteins encoded by different influenza virus subtypes.

\section{Methods}

\section{Virus isolates}

This study examined the NS1 proteins encoded by seven strains of influenza A viruses including the newly emerged 2009 pandemic H1N1 (A/Auckland/1/2009) (2009 pdmH1N1), an H2 subtype (A/Asia/57/3) (H2N2), an $\mathrm{H} 5 \mathrm{~N} 1$ isolated from a fatal case in Thailand (A/Thai/ KAN1/2004) (H5N1/2004), an H7N3 isolate (A/Canada/
504/2004) (H7N3/2004) which caused conjunctivitis and mild upper respiratory tract infection in humans in Canada, an H9N2 isolate (A/Duck/Hong Kong/Y280/ 1997) (H9N2/1997) that was closely related to those strains found in human H9N2 infections in Hong Kong, and two previous circulating seasonal influenza strains isolated in 2002 (A/HongKong/CUHK-13003/2002) (H1N1/2002) and 2004 (A/HongKong/CUHK-22910/ 2004) (H3N2/2004). Stocks of these viruses grown in Mandin-Darby canine kidney (MDCK) cells were used.

\section{Cell cultures}

The bronchial epithelial cell line, NCI-H292, derived from human lung mucoepidermoid carcinoma cells (ATCC, CRL-1848, Rockville, MD, USA), were grown as monolayers in RPMI-1640 medium (Invitrogen, Carlsbad, CA) supplemented with $10 \%$ fetal bovine serum (FBS), $100 \mathrm{U} / \mathrm{mL}$ penicillin and $100 \mu \mathrm{g} / \mathrm{mL}$ streptomycin (all from Gibco, Life Technology, Rockville, $\mathrm{Md}$., USA) at $37^{\circ} \mathrm{C}$ in a $5 \% \mathrm{CO}_{2}$ incubator. $\mathrm{NCI}$ H292 cells were used to study the host cellular response to NS1 proteins.

\section{In-vitro transcription of NS1 mRNA}

Viral NS1 mRNA was prepared from an in-vitro transcription system. Total RNA was extracted from virusinfected cell lysates using the TRIzol-total RNA extraction kit (Invitrogen). The extracted RNA was eluted in $30 \mu \mathrm{L}$ of nuclease-free water, and stored in aliquots at $-80^{\circ} \mathrm{C}$ until used. In order to avoid contamination with genomic DNA, the extracted preparation was treated with DNA-Free DNase (Invitrogen). The quality of extracted RNA preparation was assessed by measuring optical density at 260/280 nm with the NanoDrop ND1000 spectrophotometer (NanoDrop Technologies, Wilmington, DE). cDNA were reversely transcribed from RNA using the SuperScript ${ }^{\mathrm{TM}}$ III reverse transcriptase (Invitrogen). DNA fragments containing the coding region of the NS1 gene were linked to a T7 promoter sequence, with or without "hexa histidine-tag" and a polyA tail was created at the end of the fragment by PCR. The PCR was performed using the Platinum ${ }^{\circledR}$ Taq DNA polymerase high fidelity (Invitrogen). The primers used for the amplification are listed in Table 1. In-vitro transcription was performed using the mMESSAGE mMachine T7 Ultra kit (Ambion, Austin, TX, USA) with $2 \mathrm{~h}$ incubation at $37^{\circ} \mathrm{C}$. The mRNA was TURBO DNase treated for $15 \mathrm{~min}$ at $37^{\circ} \mathrm{C}$. Polyadenylation was also performed. The mRNA products were then purified using the MEGAclear kit (Ambion). The quantity and quality of capped mRNA produced was analyzed by measuring optical density at $260 / 280 \mathrm{~nm}$ with the NanoDrop ND-1000 spectrophotometer (NanoDrop Technologies) and by denaturing gel electrophoresis. 
Table 1 Primers used for amplification of NS1 genes.

\begin{tabular}{|c|c|}
\hline Influenza subtypes & Primer sequences \\
\hline H1N1/2002 & $\begin{array}{l}\text { Forward: 5'- GATCCTAATACGACTCACTATAGGGAGGAGCAAAAGCAGGGTGGCAA-3' } \\
\text { Reverse: 5'- } 11111111111111111 \text { ITTAGAAACAAGGGTGTIIIITATCATT-3' }\end{array}$ \\
\hline 2009 pdmH1N1 & $\begin{array}{l}\text { Forward: 5'- GGATCCTAATACGACTCACTATAGGGAGGAGCAAAAGCAGGGTGACAA-3' } \\
\text { Reverse: 5'- } 11111111111111111 \text { GTAGAAACAAGGGTGTIIITATCATT-3' }\end{array}$ \\
\hline $\mathrm{H} 2 \mathrm{~N} 2$ & $\begin{array}{l}\text { Forward: 5'- GGATCCTAATACGACTCACTATAGGGAGGAGCAAAAGCAGGGTGACAA-3' } \\
\text { Reverse: 5'- } 1111111111111111111 \text { GTAGAAACAAGGGTGTIIIIATCATT-3' }\end{array}$ \\
\hline H3N2/2004 & $\begin{array}{l}\text { Forward: 5'- GGATCCTAATACGACTCACTATAGGGAGGAGCAAAAGCAGGGTGACAA-3' } \\
\text { Reverse: 5'- } 1111111111111111 T G T A G A A A C A A G G G T G T I I I T A T C A T T-3^{\prime}\end{array}$ \\
\hline H5N1/2004 & 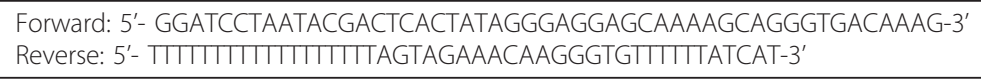 \\
\hline H7N3/2004 & $\begin{array}{l}\text { Forward: 5'- GGATCCTAATACGACTCACTATAGGGAGGAGCAAAAGCAGGGTGACAA-3' } \\
\text { Reverse: 5'- TIIIIIIIIIIIIIITGTAGAAACAAGGGTGTIIITATCATT-3' }\end{array}$ \\
\hline H9N2/1997 & $\begin{array}{l}\text { Forward: 5'- GGATCCTAATACGACTCACTATAGGGAGGAGCAAAAGCAGGGTGACAA-3' } \\
\text { Reverse: 5'- TITाTाTाTाTाTाTाTGTAGAAACAAGGGTGTITITATCATT-3' }\end{array}$ \\
\hline
\end{tabular}

\section{Transient transfection system}

Approximately $1 \times 10^{6} \mathrm{NCI}-\mathrm{H} 292$ cells were transfected with $4 \mu \mathrm{g}$ of NS1 mRNA in a six-well plate using Lipofectamine $^{\mathrm{TM}} 2000$ (Invitrogen). Briefly, NS1 mRNA and Lipofectamine $^{\mathrm{TM}} 2000$ were incubated together for 30 min in $500 \mu \mathrm{L}$ of Opti-MEM I before adding to the cells. The transfection efficiency was calculated from the percentage of fluorescent cells that were observed using florescence microscopy after the transfection of fluorescein isothiocyanate (FITC)-labeled short nucleotide primers in separate controls. The transfection efficiency was about $70 \%$. In another control, the effect of the transfection of synthetic double-stranded RNA polyriboinosinic polyribocytidylic acid [poly(I:C)] (Sigma, St Louis, MO), on cytokines/chemokines and apoptosis induction were also observed and took into account for the net effect of mRNA transfection of the experimental cells. The experimentally transfected cells were then collected at 3, 6, 18 and $24 \mathrm{~h}$ post-transfection; washed with phosphate-buffered saline (PBS) and trypsinized. After harvesting by centrifugation, the cells were resuspended in a small volume $(200-400 \mu \mathrm{L})$ of PBS for propidium iodide (PI) staining and FITC-conjugated annexin V (Annexin V-FITC) staining of apoptotic cells.

\section{Western blot analysis}

The mRNA-transfected or non-transfected cell monolayers were lysed, and the total protein concentration was determined by the bicinchoninic acid assay (BCA) (Sigma, St. Louis, MO). Proteins with equivalent concentration were heated for $5 \mathrm{~min}$ at $100^{\circ} \mathrm{C}$ in sample buffer containing $\beta$-mercaptoethanol, and were then resolved by $12 \%$ or $15 \%$ SDS-PAGE. The resolved proteins were transferred to PVDF membrane (Bio-Rad, Richmond, CA) and blocked with $1 \%$ powdered milk in Tris-buffered saline with $0.1 \%$ Tween 20 (Amersham Pharmacia, Uppsala, Sweden) for $1 \mathrm{~h}$ at room temperature. Mouse or rabbit antibodies were then used to probe for His-tagged NS1 (Invitrogen), with overnight incubation at $4^{\circ} \mathrm{C}$. The membrane was subsequently incubated for $1 \mathrm{~h}$ at room temperature with 1:1000 anti-mouse IgG horseradish peroxidase-linked whole secondary antibody (Amersham Pharmacia, Uppsala, Sweden). The membrane was also probed for GAPDH as a loading control (Chemicon, Temecula, CA).

\section{Quantification of cytokine/chemokine protein expression using cytometric bead array (CBA)}

Cell culture supernatant was collected at 0, 3, 6, 18 and $24 \mathrm{~h}$ post-transfection for cytokine/chemokine measurement by the Cytometric Bead Array (CBA) Soluble Protein Flex Set system (BD Biosciences, San Jose, CA) using the BD FACSAria Flow Cytometer System (BD Biosciences) according to the manufacturer's instructions. Six cytokines/chemokines (CCL-2/MCP-1, CCL-3/ MIP-1 $\alpha$, CCL-5/RANTES, CXCL-9/MIG, CXCL-10/IP10, IL-6) were measured. The results were expressed as number of fold changes with reference to the levels of non-transfected cell controls. All experiments were performed in triplicates.

\section{Propidium iodide (PI) staining and DNA content analysis by flow cytometry}

The overall (early and late phases together) proportion of apoptotic cells was measured by PI flow cytometric assay which is based on the principle that apoptotic cells are characterized by DNA fragmentation and the consequent loss of nuclear DNA content at the late phase of apoptosis. Briefly, transfected cells $\left(10^{6}\right)$ were washed with PBS and fixed with $70 \%$ ethanol overnight at $4^{\circ} \mathrm{C}$. The fixed cells were then stained with $50 \mu \mathrm{g} / \mathrm{mL}$ of PI (Sigma, St. Louis, MO) with $1 \mu \mathrm{g}$ of RNase A/mL at $4^{\circ} \mathrm{C}$ for $1 \mathrm{~h}$. PI binds to DNA by intercalating between the bases, with no sequence preference. The 
DNA contents of the cells were then analyzed by flow cytometry (FACSAria; BD Biosciences, San Jose, CA). Cells at the late phase of apoptosis, i.e., sub-G1 (hypodiploid) cells, will have DNA contents lower than those of G1 cells. The proportions of these apoptotic cells, i.e., sub-G1 cells, at different time points post-transfection were determined. Staurosporine-treated cells were also used as a positive control. All experiments were performed in triplicates.

Annexin V-FITC staining of apoptotic cells and analysis by flow cytometry

Annexin V-FITC staining was used to measure the proportion of cells that were at the early phase of apoptosis. Cells were collected, washed with PBS, and stained with FITC-conjugated annexin V (BD Biosciences, Franklin Lakes, NJ) and PI for $20 \mathrm{~min}$ at room temperature in dark. The stained cells were then analyzed by flow cytometry (FACSAria; BD Biosciences). FITC-conjugated annexin $\mathrm{V}$ binds to surface phosphatidylserine translocated from the intra- to the extracellular plasma membrane early in apoptosis. Cells were simultaneously stained with PI to discriminate membrane-permeable necrotic cells from FITC-labeled apoptotic cells. Apoptotic cells were identified as those with annexin V-FITC staining only, and the results were expressed as the proportion of these cells among the total number of cells analyzed. Staurosporine-treated cells were also used as a positive control. All experiments were performed in triplicates.

\section{Results}

Cytokine/chemokine expression profiles

Different profiles of cytokine/chemokine expression were observed following the transfection of NS1 mRNA derived from various influenza subtypes (Figure 1).
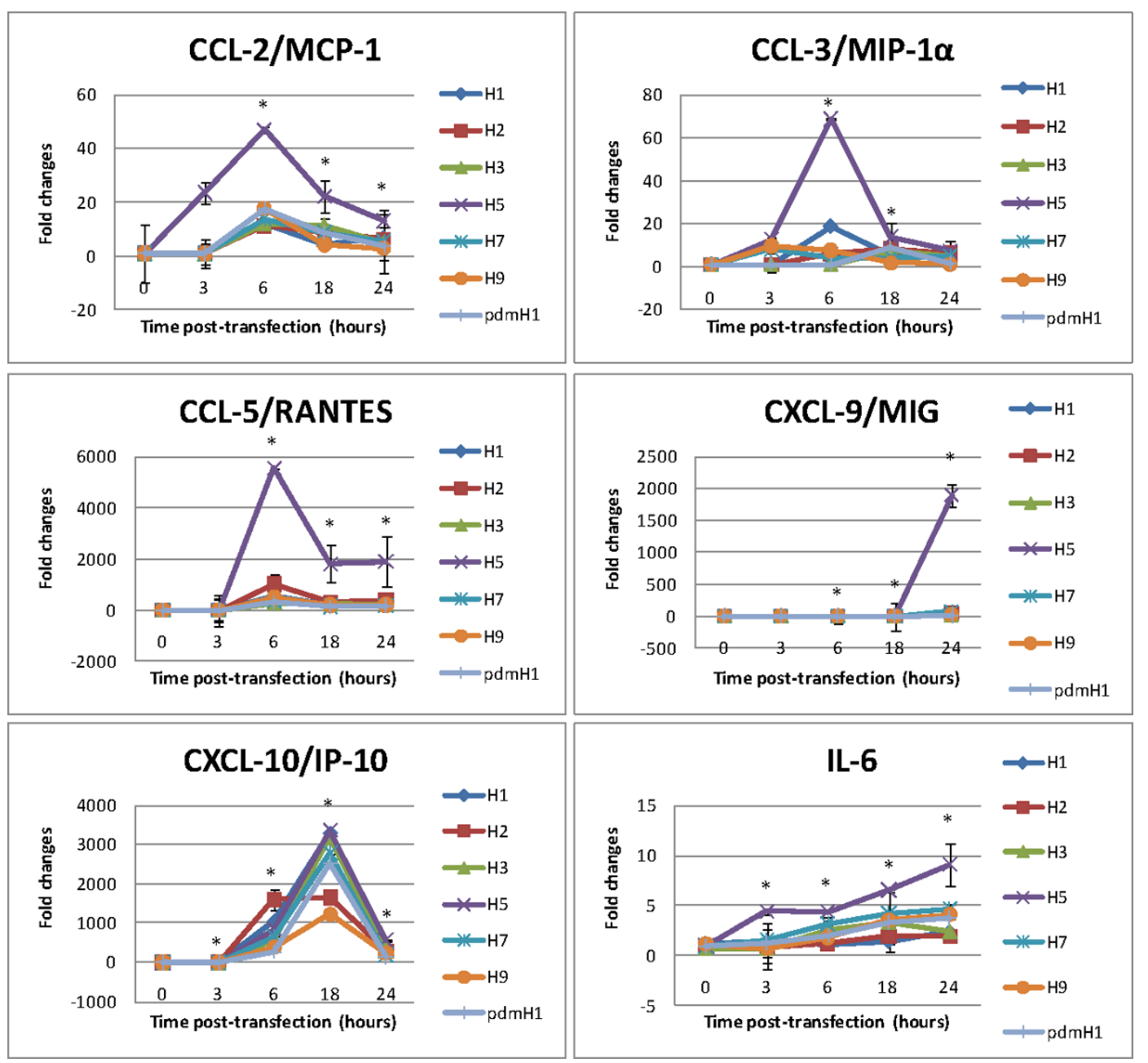

Figure 1 Cytokines/chemokines induced by transfection of NS1 mRNA of different influenza subtypes. NCI-H292 cells were transfected with NS1 mRNA derived from seven subtypes of influenza A including seasonal H1N1 (H1), H2N2, H3N2, H5N1, H7N3, H9N2 and 2009 pandemic H1N1 (pdmH1). Cytokine/chemokine levels are expressed as fold-changes compared to the non-transfected cell controls \pm SD $\left(p^{*}<0.05\right)$ measured at the same time points. 
Overall, the most prominent induction was observed for CXCL-10/IP-10 regardless of influenza subtype, and with $>1,000$-fold increase at peak induction. IL-6 was also induced by all subtypes but to a much lower extent ( $<10$-fold increase at peak induction). A distinct pattern in induction between $\mathrm{H} 5$ and other subtypes was observed for CCL-2/MCP-1, CCL-3/MIP-1 $\alpha$, CCL-5/ RANTES and CXCL-9/MIG. For all these four cytokines/chemokines, the level of expression induced by $\mathrm{H} 5$ was much higher than other subtypes.

The six studied cytokines/chemokines can be divided in to two groups according to the time to reach peak level of induction. The "early" group included CCL-2/ MCP-1, CCL-3/MIP- $1 \alpha$ and CCL-5/RANTES showing a peak at $6 \mathrm{~h}$ post-transfection. All members of the "early" group showed a strong response to $\mathrm{H} 5$, but they were only induced to low levels by other subtypes (Figure 1). The "late" group included IL-6, CXCL-9/MIG and CXCL-10/IP-10 showing a peak at 18-24 h post-transfection. No obvious correlation between the time to reach peak level and the subtype of virus was observed.

Among the seven subtypes of influenza examined, only $\mathrm{H} 5$ showed a distinct profile of cytokine/chemokine induction; and being the strongest inducer for all the six cytokines/chemokines. The cytokine/chemokine induction profiles observed for the recently emerged 2009 pdmH1N1-NS1 were similar to previous seasonal strains.

\section{Apoptosis}

The overall (early and late phases together) proportion of apoptotic cells for H5N1/2004-NS1 was the highest at all time points as compared to other subtypes (Figure
2). At 24 h post-transfection, $44 \%$ of H5N1-NS1-transfected cells had entered apoptosis, compared to 20-28\% of other subtypes. The 2009 pdmH1N1-, H3N2-, and H9N2-transfected cells showed a relatively higher proportion of apoptosis (25-29\%) at $18 \mathrm{~h}$ post-transfection; however these subtypes reached similar levels as compared to other non-H5 subtypes at $24 \mathrm{~h}$ post-transfection (Figure 2).

Figure 3 shows the proportion of cells at the early phase of apoptosis at different time points post-transfection. Overall, apoptotic activity was the highest at $6 \mathrm{~h}$ post-transfection, and then decreased gradually. This time course of apoptosis was similar among the different subtypes of influenza viruses examined. Figure 3 displays the distinct apoptotic induction ability of H5N1 as compared to other subtypes. At the peak of apoptotic activity (6 $\mathrm{h}$ post-transfection), the proportion of apoptotic cells for $\mathrm{H} 5 \mathrm{~N} 1$ was about twice higher than those for other subtypes. The newly emerged 2009 pdmH1N1NS1 showed a moderate ability in inducing apoptosis. At both $6 \mathrm{~h}$ and $18 \mathrm{~h}$ post-transfection, the proportion of early apoptotic cells ranked second, just following H5N1/2004-NS1, among the subtypes examined.

\section{Discussion}

In this study, the pathogenic properties of NS1 proteins encoded by different subtypes of influenza A viruses were compared by measuring cytokine/chemokine expression and apoptosis induced in transfected cells.

While the key target of influenza virus is lung epithelial cells $[48,49]$, most studies on influenza pathogenesis have been based on macrophages and monocytes infected in-vitro or in-vivo [50-52]. It is important to

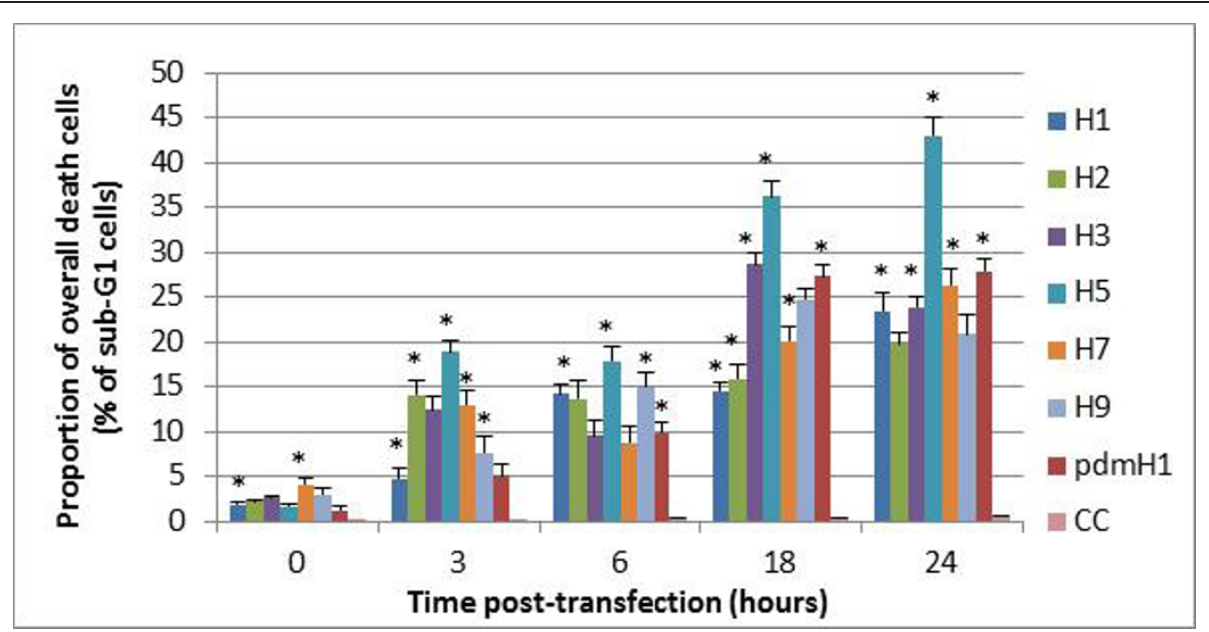

Figure 2 Proportion of overall apoptotic cells induced by transfection of NS1 mRNA of different influenza subtypes. NCI-H292 cells were transfected with NS1 mRNA derived from seven subtypes of influenza A including seasonal H1N1 (H1), H2N2, H3N2, H5N1, H7N3, H9N2 and 2009 pandemic H1N1 (pdmH1). CC represents non-transfected controls. The overall proportion of death cells was measured by propidium iodide staining using flow cytometry with the sub-G1 cell proportion counted $\pm \mathrm{SD}\left(p^{*}<0.05\right)$. 


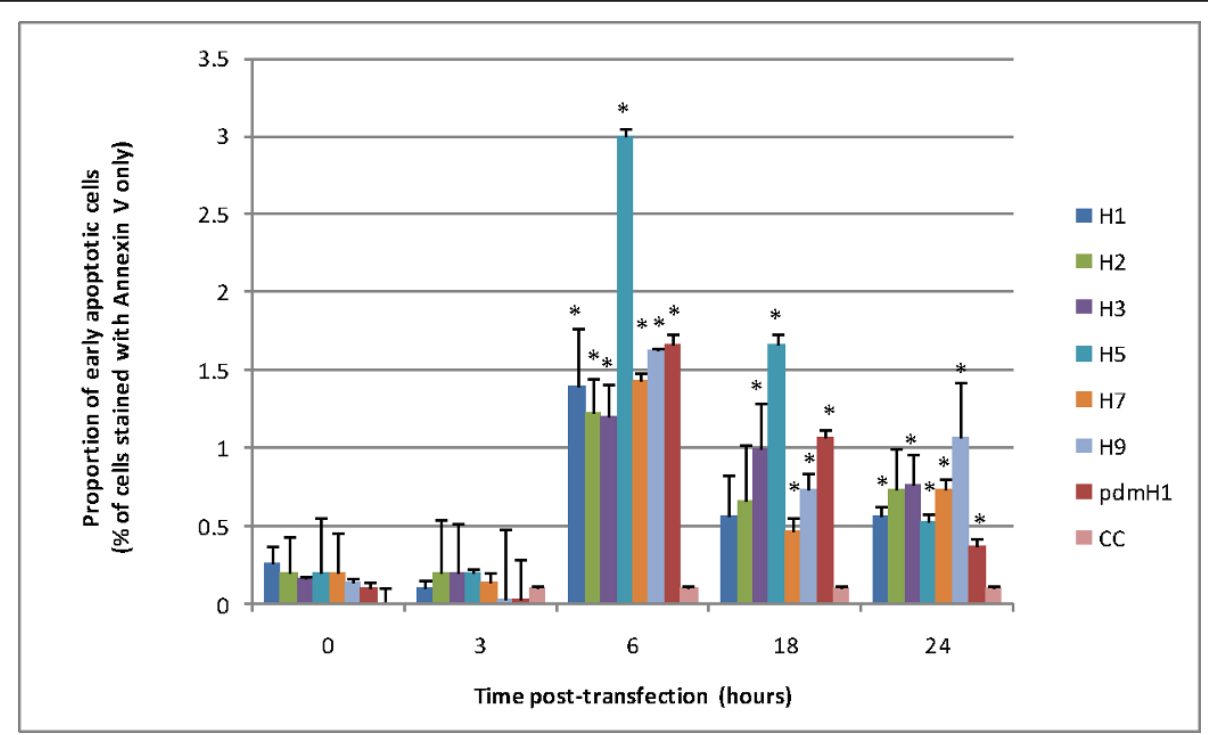

Figure 3 Proportion of early apoptotic cells induced by transfection of NS1 mRNA of different influenza subtypes. NCI-H292 cells were transfected with NS1 mRNA derived from seven subtypes of influenza A including seasonal H1N1 (H1), H2N2, H3N2, H5N1, H7N3, H9N2 and 2009 pandemic H1N1 (pdmH1). CC represents non-transfected controls. Cells at early apoptotic phase as stained positive for annexin $V$ but not propidium iodide were identified by flow cytometry \pm SD $\left(p^{*}<0.05\right)$.

note that at the time of early infection these immune cells would not be present in great numbers until they have been recruited into the area. The mechanism concerning bronchial infiltration of inflammatory cells, particularly lymphocytes and eosinophils, and the subsequent hyperresponsiveness of the bronchial wall induced by viruses remain unclear [53]. Therefore, in this study we have used a cell line derived from human lung epithelial cells as an in-vitro model to study the pathogenicity of influenza NS1 proteins.

Previous in-vitro studies have shown that influenza infection induces the production of cytokines IFN- $\alpha$, tumor necrosis factor (TNF)- $\alpha, \mathrm{IL}-1, \mathrm{IL}-6, \mathrm{IL}-8$ and the mononuclear cell attractant chemokines CCL-3/MIP-1 $\alpha$, CCL-4/MIP-1 $\beta$, CCL-2/MCP-1, CCL-7/MCP-3, CXCL10/IP-10 and CCL-5/RANTES in human monocytes, epithelial cells, rat alveolar or murine macrophages [48,50,53-62]. Based on the findings of these studies, we identified the six key cytokines/chemokines for the current study.

Recently, it has been shown that the inflammatory response is played out over time in a reproducible and organized way with different induction kinetics after an initiating stimulus [63]. Cytokines released following infection can be classified broadly into "early" and "late" cytokines. Our results showed that CCL-2/MCP-1, CCL-3/MIP- $1 \alpha$ and CCL-5/RANTES were produced early post-transfection; while IL-6, CXCL-10/IP-10 and CXCL-9/MIG were produced later. This time course of cytokine/chemokine production was consistently observed across different subtypes of influenza viruses with different pathogenicity. It would be worthwhile to further investigate whether this temporal sequence is unique to influenza or generally true for other acute respiratory viruses.

The most remarkable observation in this study was the distinct cytokine/chemokine profiles induced by the NS1 protein of H5N1. Our in-vitro observation is in line with previous reports that the peripheral blood of patients infected with $\mathrm{H} 5 \mathrm{~N} 1$ have much higher serum levels of CXCL-10/IP-10 and CCL-2/MCP-1 than patients infected with seasonal influenza $[13,15]$. Furthermore, the in-vitro model used in our study by measuring the levels of cytokines in lung tissue may be more relevant to pathogenesis than levels in blood [15]. Another in-vitro study in macrophages also showed a stronger cytokine induction by H5N1/1997 viruses compared to H3N2 [51].

We found that NS1 protein encoded by 2009 pdmH1N1 virus induced similar levels of cytokine/chemokine compared to seasonal H1N1 and H3N2 strains. This observation is in line with a recent report which showed that pro-inflammatory cytokine expression in the 2009 pandemic H1N1 virus-infected macrophages was similar to that of seasonal $\mathrm{H} 1 \mathrm{~N} 1 / 1999$, and was much lower than in H5N1/2004-infected cells [64-67].

In this study, we observed a similar temporal profile of apoptosis as induced by different subtypes of influenza. This is in contrast to previous studies based on whole virions. For instance, Geiler et al. (2011) [67] reported a 
delay in the induction of apoptosis for 2009 pdmH1N1 compared to H5N1; whereas Mok et al. (2007) [68] reported a delayed apoptosis of $\mathrm{H} 5 \mathrm{~N} 1$ compared to seasonal H1N1. The reason for these different observations remains to be verified. Both of these two studies $[67,68]$ used whole virions, and therefore the observation may be partly related to the time required for sufficient virus replication and hence the synthesis of a certain amount of NS1 protein; whereas the current study used transfection where the same amount of NS1 was expected to be synthesized at any one time for different subtypes. If NS1 protein per se was the question of interest, using transfection methods with the same transfection efficiencies among different subtypes, might avoid biases result from differences in replication efficiency of the viruses being studied. Another major difference is that in contrast to the lung epithelial cells used in our study, the two previous studies used macrophages. These two cell types may display differences in apoptotic response to different subtypes of influenza.

Another remarkable observation of the current study is the high apoptosis inducing ability conferred by NS1 protein encoded by $\mathrm{H} 5 \mathrm{~N} 1$ compared to all other subtypes. This is reminiscent of the rapid development of severe primary pneumonitis in patients infected with H5N1 [4,13-16]. Our data showed that the apoptosis inducing ability of NS1 protein encoded by 2009 pdmH1N1 virus was similar to H7, H9 and seasonal subtypes; but much lower than H5N1. This is in line with a previous observation based on macrophages infected with whole virions, where the level of apoptosis induced by 2009 pdmH1N1 was much lower than H5N1 [67].

NS1 have both pro- and anti-apoptotic functions, and the level of apoptosis observed reflects a balance between the two [30,34,69-73]. It would be worthwhile to further investigate whether the NS1 encoded by H5N1 is more pro-apoptotic or less anti-apoptotic as compared to other subtypes.

\section{Conclusions}

This study confirms that transfection of human lung epithelial cell line with NS1 mRNA is a suitable in-vitro model to delineate and compare the function of NS1 proteins encoded by different influenza subtypes. Our data indicates that NS1 protein is one of the keys for an exceptional higher pathogenicity of H5N1 compared to other avian and human subtypes. The NS1 protein encoded by 2009 pdmH1N1 exhibits a similar pro-inflammatory and apoptosis inducing ability as with other human seasonal subtypes, reflecting their similarity in pathogenicity. It is worthwhile to further explore the potential of using NS1 protein as a target of therapeutic intervention.

\section{Abbreviations}

2009 pdmH1N1: 2009 pandemic H1N1 influenza virus; Annexin V-FITC: fluorescein isothiocyanate-conjugated annexin $\mathrm{V}$ staining; $\mathrm{BCA}$ : bicinchoninic acid assay; CBA: Cytometric Bead Array; CCL-2/MCP-1: Chemokine (C-C motif) ligand 2/monocyte chemotactic protein-1; CCL-3/MIP-1a: Chemokine (C-C motif) ligand 3/Macrophage inflammatory protein-1a; CCL-4/MIP-1 $\beta$ : Chemokine (C-C motif) ligand 3/Macrophage inflammatory protein-1 $\beta$; $C C L-$ 5/RANTES: Chemokine (C-C motif) ligand 5/Regulated upon Activation, Normal T-cell Expressed, and Secreted; CCL-7/MCP-3: Chemokine (C-C motif) ligand 2/monocyte chemotactic protein-3; cDNA: complementary Deoxyribonucleic Acid; CXCL-9/MIG: Chemokine (C-X-C motif) ligand 9/ Monokine induced by gamma interferon; CXCL-10/IP-10: C-X-C motif chemokine 10/Interferon gamma-induced protein 10; FBS: fetal bovine serum; FITC: fluorescein isothiocyanate; GAPDH: Glyceraldehyde 3-phosphate dehydrogenase; HA: hemagglutinin; H1N1/2002: (A/HongKong/CUHK-13003/ 2002); H2N2: H2 subtype (A/Asia/57/3); H3N2/2004: (A/HongKong/CUHK22910/2004); H5N1/2004: (A/Thai/KAN1/2004); H7N3/2004: (A/Canada/504/ 2004); H9N2: (A/Duck/Hong Kong/Y280/1997); IFN-a: Interferon alpha; IFN- $\beta$ : Interferon beta; IgG: immunoglobulin G; IL-1: Interleukin 1; IL-6: Interleukin 6; IL-8: Interleukin 8; M1: matrix protein 1; M2: matrix protein 2; MDCK cells: Mandin-Darby canine kidney cells; mRNA: messenger Ribonucleic Acid; NA: neuraminidase; NP: nucleoprotein; NS1: non-structural protein 1; NS2: nonstructural protein 2; PA: polymerase acidic protein; PB1: polymerase basic protein 1; PB2: polymerase basic protein 2; PBS: phosphate-buffered saline; PI staining: propidium iodide staining; PI3-kinase: phosphatidylinositol-3-kinase; PKR: double-stranded-RNA-activated protein kinase; poly(l:C): polyriboinosinic polyribocytidylic acid; PVDF membrane: Polyvinylidene fluoride membrane; RIG-I: retinoic acid-inducible gene product I; RNaseL: 2-5A-dependent ribonuclease; RPMI-1640 medium: Roswell Park Memorial Institute 1640 medium; SDS-PAGE: sodium dodecyl sulfate polyacrylamide gel electrophoresis; TNF-a: tumor necrosis factor-a; WHO: World Health Organization

\section{Acknowledgements}

We thank Prof. Pilaipan Puthavathana for provision of A/Thailand/1(KAN-1)/2004 (H5N1) isolate; Dr. Yan Li for provision of A/Canada/504/2004 (H7N3) isolate; Prof. Malik Peiris for provision of A/Duck/Hong Kong/Y280/1997 (H9N2) isolate and Dr. lan G Barr for provision of the pandemic H1N1 viral RNA (A/Auckland/1/ 2009). This study was supported by the Research Fund for the Control of Infectious Diseases, Food and Health Bureau, the Government of the Hong Kong Special Administrative Region (Project code: CU-09-01-04-Lab-3).

\section{Author details}

'Department of Microbiology, Faculty of Medicine. The Chinese University of Hong Kong, 1/F Clinical Sciences Building, Prince of Wales Hospital, Shatin, New Territories, Hong Kong Special Administration Region of the People's Republic of China. ${ }^{2}$ Stanley Ho Centre for Emerging Infectious Diseases, Faculty of Medicine, The Chinese University of Hong Kong, New Territories, Hong Kong Special Administration Region of the People's Republic of China.

\section{Authors' contributions}

ACMY performed the in-vitro transcription assays, RT-PCR assays, apoptotic cells staining and flow-cytometry assays. WYL was responsible for experimental design, analyses and drafting of the manuscript. PKSC was responsible for design and supervision of the study. All authors read and approved the final manuscript.

\section{Competing interests}

The authors declare that they have no competing interests.

Received: 17 May 2011 Accepted: 21 December 2011

Published: 21 December 2011

\section{References}

1. Claas EC, Osterhaus AD, van Beek R, De Jong JC, Rimmelzwaan GF, Senne DA, Krauss S, Shortridge KF, Webster RG: Human influenza A H5N1 virus related to a highly pathogenic avian influenza virus. Lancet 1998, 351:472-477.

2. Yuen KY, Chan PK, Peiris M, Tsang DN, Que TL, Shortridge KF, Cheung PT, To WK, Ho ET, Sung R, et al: Clinical features and rapid viral diagnosis of 
human disease associated with avian influenza A H5N1 virus. Lancet 1998, 351:467-471.

3. Peiris M, Yuen KY, Leung CW, Chan KH, Ip PL, Lai RW, Orr WK, Shortridge KF: Human infection with influenza H9N2. Lancet 1999, 354:916-917.

4. To KF, Chan PK, Chan KF, Lee WK, Lam WY, Wong KF, Tang NL, Tsang DN, Sung RY, Buckley TA, et al: Pathology of fatal human infection associated with avian influenza A H5N1 virus. J Med Virol 2001, 63:242-246.

5. Chan PK: Outbreak of avian influenza $A(\mathrm{H} 5 \mathrm{~N} 1)$ virus infection in Hong Kong in 1997. Clin Infect Dis 2002, 34(Suppl 2):S58-S64.

6. Fouchier RA, Schneeberger PM, Rozendaal FW, Broekman JM, Kemink SA, Munster V, Kuiken T, Rimmelzwaan GF, Schutten M, Van Doornum GJ, et al: Avian influenza A virus (H7N7) associated with human conjunctivitis and a fatal case of acute respiratory distress syndrome. Proc Natl Acad Sci USA 2004, 101:1356-1361.

7. Yamada S, Suzuki Y, Suzuki T, Le MQ, Nidom CA, Sakai-Tagawa Y, Muramoto $Y$, Ito $M$, Kiso M, Horimoto $T$, et al: Haemagglutinin mutations responsible for the binding of $\mathrm{H} 5 \mathrm{~N} 1$ influenza A viruses to human-type receptors. Nature 2006, 444:378-382.

8. Abdel-Ghafar AN, Chotpitayasunondh T, Gao Z, Hayden FG, Nguyen DH, de Jong MD, Naghdaliyev A, Peiris JS, Shindo N, Soeroso S, et al: Update on avian influenza A (H5N1) virus infection in humans. N Engl J Med 2008, 358:261-273.

9. World Health Organization: Cumulative number of confirmed human cases of avian influenza $\mathrm{A} /(\mathrm{H} 5 \mathrm{~N} 1)$ reported to WHO. World Health Organization, Geneva, Switzerland; 2011 [http://www.who.int/influenza/ human_animal_interface/EN_GIP_20111215CumulativeNumberH5N1cases. pdf].

10. Centers for Disease Control and Prevention (CDC): Update: influenza activity-United States, August 30, 2009-March 27, 2010, and composition of the 2010-11 influenza vaccine. Morb Mortal Wkly Rep 2010, 59:423-430.

11. Bautista E, Chotpitayasunondh T, Gao Z, Harper SA, Shaw M, Uyeki TM, Zaki SR, Hayden FG, Hui DS, Kettner JD, et al: Clinical aspects of pandemic 2009 influenza A (H1N1) virus infection. N Engl J Med 2010, 362:1708-1719.

12. Lee N, Chan PK, Wong CK, Wong KT, Choi KW, Joynt GM, Lam P, Chan MC, Wong BC, Lui GC, Sin WW, Wong RY, Lam WY, Yeung AC, Leung TF, So HY, Yu AW, Sung JJ, Hui DS: Viral clearance and inflammatory response patterns in adults hospitalized for pandemic 2009 influenza $A(H 1 N 1)$ virus pneumonia. Antivir Ther 2011, 16::237-47.

13. Peiris JS, Yu WC, Leung CW, Cheung CY, Ng WF, Nicholls JM, Ng TK, Chan KH, Lai ST, Lim WL, et al: Re-emergence of fatal human influenza A subtype H5N1 disease. Lancet 2004, 363:617-619.

14. de Jong MD, Hien TT: Avian influenza A (H5N1). J Clin Virol 2006, 35:2-13

15. de Jong MD, Simmons CP, Thanh TT, Hien VM, Smith GJ, Chau TN, Hoang DM, Chau NV, Khanh TH, Dong VC, et al: Fatal outcome of human influenza $\mathrm{A}(\mathrm{H} 5 \mathrm{~N} 1)$ is associated with high viral load and hypercytokinemia. Nat Med 2006, 12:1203-1207.

16. de Jong MD: H5N1 transmission and disease: observations from the frontlines. Pediatr Infect Dis J 2008, 27:S54-S56.

17. Brydon EW, Morris SJ, Sweet C: Role of apoptosis and cytokines in influenza virus morbidity. FEMS Microbiol Rev 2005, 29:837-850.

18. Korteweg C, Gu J: Pathology, molecular biology, and pathogenesis of avian influenza A (H5N1) infection in humans. Am J Pathol 2008, 172:1155-1170.

19. Hatta M, Gao P, Halfmann P, Kawaoka Y: Molecular basis for high virulence of Hong Kong H5N1 influenza A viruses. Science 2001, 293:1840-1842

20. Geiss GK, Salvatore M, Tumpey TM, Carter VS, Wang X, Basler CF, Taubenberger JK, Bumgarner RE, Palese P, Katze MG, et al: Cellular transcriptional profiling in influenza A virus-infected lung epithelial cells: the role of the nonstructural NS1 protein in the evasion of the host innate defense and its potential contribution to pandemic influenza. Proc Natl Acad Sci USA 2002, 99:10736-10741.

21. Tumpey TM, Garcia-Sastre A, Taubenberger JK, Palese P, Swayne DE, Basler CF: Pathogenicity and immunogenicity of influenza viruses with genes from the 1918 pandemic virus. Proc Natl Acad Sci USA 2004, 101:3166-3171.

22. Glaser L, Stevens J, Zamarin D, Wilson IA, Garcia-Sastre A, Tumpey TM, Basler CF, Taubenberger JK, Palese P: A single amino acid substitution in
1918 influenza virus hemagglutinin changes receptor binding specificity. J Virol 2005, 79:11533-11536.

23. Tumpey TM, Basler CF, Aguilar PV, Zeng H, Solorzano A, Swayne DE, Cox NJ, Katz JM, Taubenberger JK, Palese P, et al: Characterization of the reconstructed 1918 Spanish influenza pandemic virus. Science 2005, 310:77-80

24. Kash JC, Tumpey TM, Proll SC, Carter V, Perwitasari O, Thomas MJ, Basler CF, Palese P, Taubenberger JK, Garcia-Sastre A, et al: Genomic analysis of increased host immune and cell death responses induced by 1918 influenza virus. Nature 2006, 443:578-581.

25. Taubenberger JK: The origin and virulence of the 1918 "Spanish" influenza virus. Proc Am Philos Soc 2006, 150:86-112.

26. Zamarin D, Ortigoza MB, Palese P: Influenza A virus PB1-F2 protein contributes to viral pathogenesis in mice. J Virol 2006, 80:7976-7983.

27. Chen H, Bright RA, Subbarao K, Smith C, Cox NJ, Katz JM, Matsuoka Y: Polygenic virulence factors involved in pathogenesis of 1997 Hong Kong H5N1 influenza viruses in mice. Virus Res 2007, 128:159-163.

28. Hatta M, Hatta $Y$, Kim JH, Watanabe S, Shinya K, Nguyen T, Lien PS, Le QM, Kawaoka Y: Growth of H5N1 influenza A viruses in the upper respiratory tracts of mice. PLoS Pathog 2007, 3:1374-1379.

29. Vreede FT, Jung TE, Brownlee GG: Model suggesting that replication of influenza virus is regulated by stabilization of replicative intermediates. $J$ Virol 2004, 78:9568-9572.

30. Falcon AM, Marion RM, Zurcher T, Gomez P, Portela A, Nieto A, Ortin J: Defective RNA replication and late gene expression in temperaturesensitive influenza viruses expressing deleted forms of the NS1 protein. J Virol 2004, 78:3880-3888.

31. Min JY, Li S, Sen GC, Krug RM: A site on the influenza A virus NS1 protein mediates both inhibition of PKR activation and temporal regulation of viral RNA synthesis. Virology 2007, 363:236-243.

32. Hale BG, Jackson D, Chen YH, Lamb RA, Randall RE: Influenza A virus NS1 protein binds p85beta and activates phosphatidylinositol-3-kinase signaling. Proc Natl Acad Sci USA 2006, 103:14194-14199.

33. Ehrhardt C, Wolff T, Pleschka S, Planz O, Beermann W, Bode JG, Schmolke M, Ludwig S: Influenza A virus NS1 protein activates the PI3K/ Akt pathway to mediate antiapoptotic signaling responses. J Virol 2007, 81:3058-3067.

34. Shin YK, Liu Q, Tikoo SK, Babiuk LA, Zhou Y: Influenza A virus NS1 protein activates the phosphatidylinositol 3-kinase (PI3K)/Akt pathway by direct interaction with the p85 subunit of PI3K. J Gen Virol 2007, 88:13-18.

35. Zhirnov OP, Klenk HD: Control of apoptosis in influenza virus-infected cells by up-regulation of Akt and p53 signaling. Apoptosis 2007, 12:1419-1432.

36. Min JY, Krug RM: The primary function of RNA binding by the influenza A virus NS1 protein in infected cells: Inhibiting the $2^{\prime}-5$ ' oligo (A) synthetase/RNase L pathway. Proc Natl Acad Sci USA 2006, 103:7100-7105.

37. Talon J, Horvath CM, Polley R, Basler CF, Muster T, Palese P, Garcia-Sastre A: Activation of interferon regulatory factor 3 is inhibited by the influenza A virus NS1 protein. J Virol 2000, 74:7989-7996.

38. Wang X, Li M, Zheng H, Muster T, Palese P, Beg AA, Garcia-Sastre A: Influenza $A$ virus NS1 protein prevents activation of NF-kappaB and induction of alpha/beta interferon. J Virol 2000, 74:11566-11573.

39. Ludwig S, Wang X, Ehrhardt C, Zheng H, Donelan N, Planz O, Pleschka S, Garcia-Sastre A, Heins G, Wolff T: The influenza A virus NS1 protein inhibits activation of Jun N-terminal kinase and AP-1 transcription factors. J Virol 2002, 76:11166-11171.

40. Guo Z, Chen LM, Zeng H, Gomez JA, Plowden J, Fujita T, Katz JM, Donis RO, Sambhara S: NS1 protein of influenza A virus inhibits the function of intracytoplasmic pathogen sensor, RIG-I. Am J Respir Cell Mol Biol 2007, 36:263-269.

41. Mibayashi M, Martinez-Sobrido L, Loo YM, Cardenas WB, Gale M, GarciaSastre A: Inhibition of retinoic acid-inducible gene I-mediated induction of beta interferon by the NS1 protein of influenza A virus. J Virol 2007, 81:514-524.

42. Opitz B, Rejaibi A, Dauber B, Eckhard J, Vinzing M, Schmeck B, Hippenstiel S, Suttorp N, Wolff T: IFNbeta induction by influenza $A$ virus is mediated by RIG-I which is regulated by the viral NS1 protein. Cell Microbiol 2007, 9:930-938.

43. Nemeroff ME, Barabino SM, Li Y, Keller W, Krug RM: Influenza virus NS1 protein interacts with the cellular $30 \mathrm{kDa}$ subunit of CPSF and inhibits 3'end formation of cellular pre-mRNAs. Mol Cell 1998, 1:991-1000. 
44. Noah DL, Twu KY, Krug RM: Cellular antiviral responses against influenza A virus are countered at the posttranscriptional level by the viral NS1A protein via its binding to a cellular protein required for the $3^{\prime}$ end processing of cellular pre-mRNAS. Virology 2003, 307:386-395.

45. Bergmann M, Garcia-Sastre A, Carnero E, Pehamberger H, Wolff K, Palese $P$, Muster T: Influenza virus NS1 protein counteracts PKR-mediated inhibition of replication. J Virol 2000, 74:6203-6206.

46. Jackson D, Hossain MJ, Hickman D, Perez DR, Lamb RA: A new influenza virus virulence determinant: the NS1 protein four C-terminal residues modulate pathogenicity. Proc Natl Acad Sci USA 2008, 105:4381-4386.

47. Fernandez-Sesma A, Marukian S, Ebersole BJ, Kaminski D, Park MS, Yuen T, Sealfon SC, Garcia-Sastre A, Moran TM: Influenza virus evades innate and adaptive immunity via the NS1 protein. J Virol 2006, 80:6295-6304.

48. Matsukura S, Kokubu F, Noda H, Tokunaga H, Adachi M: Expression of IL-6, IL-8, and RANTES on human bronchial epithelial cells, NCl-H292, induced by influenza virus A. J Allergy Clin Immunol 1996, 98:1080-1087.

49. Seo SH, Webster RG: Tumor necrosis factor alpha exerts powerful antiinfluenza virus effects in lung epithelial cells. J Virol 2002, 76:1071-1076.

50. Hofmann P, Sprenger H, Kaufmann A, Bender A, Hasse C, Nain M, Gemsa D: Susceptibility of mononuclear phagocytes to influenza $A$ virus infection and possible role in the antiviral response. J Leukoc Biol 1997, 61:408-414.

51. Cheung CY, Poon LL, Lau AS, Luk W, Lau YL, Shortridge KF, Gordon S, Guan Y, Peiris JS: Induction of proinflammatory cytokines in human macrophages by influenza A (H5N1) viruses: a mechanism for the unusual severity of human disease? Lancet 2002, 360:1831-1837.

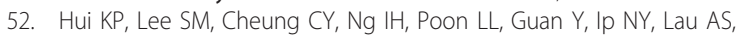
Peiris JS: Induction of proinflammatory cytokines in primary human macrophages by influenza A virus (H5N1) is selectively regulated by IFN regulatory factor 3 and p38 MAPK. J Immunol 2009, 182:1088-1098.

53. Adachi M, Matsukura S, Tokunaga $H$, Kokubu F: Expression of cytokines on human bronchial epithelial cells induced by influenza virus A. Int Arch Allergy Immunol 1997, 113:307-311.

54. Nain M, Hinder F, Gong JH, Schmidt A, Bender A, Sprenger H, Gemsa D: Tumor necrosis factor-alpha production of influenza A virus-infected macrophages and potentiating effect of lipopolysaccharides. J Immunol 1990, 145:1921-1928.

55. Choi AM, Jacoby DB: Influenza virus A infection induces interleukin-8 gene expression in human airway epithelial cells. FEBS Lett 1992, 309:327-329.

56. Bussfeld D, Kaufmann A, Meyer RG, Gemsa D, Sprenger H: Differential mononuclear leukocyte attracting chemokine production after stimulation with active and inactivated influenza A virus. Cell Immunol 1998, 186:1-7

57. Matsukura S, Kokubu F, Kubo H, Tomita T, Tokunaga H, Kadokura M, Yamamoto T, Kuroiwa Y, Ohno T, Suzaki H, et al: Expression of RANTES by normal airway epithelial cells after influenza virus $A$ infection. Am J Respir Cell Mol Biol 1998, 18:255-264.

58. Julkunen I, Melen K, Nyqvist M, Pirhonen J, Sareneva T, Matikainen S: Inflammatory responses in influenza A virus infection. Vaccine 2000 19(Suppl 1):S32-S37.

59. Matikainen S, Pirhonen J, Miettinen M, Lehtonen A, Govenius-Vintola C, Sareneva T, Julkunen I: Influenza A and sendai viruses induce differential chemokine gene expression and transcription factor activation in human macrophages. Virology 2000, 276:138-147.

60. Julkunen I, Sareneva T, Pirhonen J, Ronni T, Melen K, Matikainen S: Molecular pathogenesis of influenza A virus infection and virus-induced regulation of cytokine gene expression. Cytokine Growth Factor Rev 2001, 12:171-180.

61. Brydon EW, Smith H, Sweet C: Influenza A virus-induced apoptosis in bronchiolar epithelial ( $\mathrm{NCl}-\mathrm{H} 292)$ cells limits pro-inflammatory cytokine release. J Gen Virol 2003, 84:2389-2400.

62. Lam WY, Yeung AC, Chu IM, Chan PK: Profiles of cytokine and chemokine gene expression in human pulmonary epithelial cells induced by human and avian influenza viruses. Virol J 2010, 7:344.

63. Hao S, Baltimore D: The stability of mRNA influences the temporal order of the induction of genes encoding inflammatory molecules. Nat Immunol 2009, 10:281-288.

64. Chan RW, Yuen KM, Yu WC, Ho CC, Nicholls JM, Peiris JS, Chan MC: Influenza $\mathrm{H} 5 \mathrm{~N} 1$ and $\mathrm{H} 1 \mathrm{~N} 1$ virus replication and innate immune responses in bronchial epithelial cells are influenced by the state of differentiation. PLoS One 2010, 5:e8713.
65. Osterlund P, Pirhonen J, Ikonen N, Ronkko E, Strengell M, Makela SM, Broman M, Hamming OJ, Hartmann R, Ziegler T, et al: Pandemic H1N1 2009 influenza A virus induces weak cytokine responses in human macrophages and dendritic cells and is highly sensitive to the antiviral actions of interferons. J Virol 2010, 84:1414-1422.

66. Woo PC, Tung ET, Chan KH, Lau CC, Lau SK, Yuen KY: Cytokine profiles induced by the novel swine-origin influenza $\mathrm{A} / \mathrm{H} 1 \mathrm{~N} 1$ virus: implications for treatment strategies. J Infect Dis 2010, 201:346-353.

67. Geiler J, Michaelis M, Sithisarn P, Cinatl J Jr: Comparison of proinflammatory cytokine expression and cellular signal transduction in human macrophages infected with different influenza A viruses. Med Microbiol Immunol 2011, 200:53-60.

68. Mok CK, Lee DC, Cheung CY, Peiris M, Lau AS: Differential onset of apoptosis in influenza A virus. J Gen Virol 2007, 88:1275-1280.

69. Schultz-Cherry S, Dybdahl-Sissoko N, Neumann G, Kawaoka Y, Hinshaw VS Influenza virus ns1 protein induces apoptosis in cultured cells. J Virol 2001, 75:7875-7881.

70. Zhirnov OP, Konakova TE, Wolff T, Klenk HD: NS1 protein of influenza A virus down-regulates apoptosis. J Virol 2002, 76:1617-1625.

71. Stasakova J, Ferko B, Kittel C, Sereinig S, Romanova J, Katinger H, Egorov A: Influenza A mutant viruses with altered NS1 protein function provoke caspase-1 activation in primary human macrophages, resulting in fast apoptosis and release of high levels of interleukins 1beta and 18. J Gen Virol 2005, 86:185-195.

72. Hale BG, Randall RE, Ortin J, Jackson D: The multifunctional NS1 protein of influenza A viruses. J Gen Virol 2008, 89:2359-2376.

73. Lam WY, Tang JW, Yeung AC, Chiu LC, Sung JJ, Chan PK: Avian influenza virus $A / H K / 483 / 97(H 5 N 1)$ NS1 protein induces apoptosis in human airway epithelial cells. J Virol 2008, 82:2741-2751.

\section{doi:10.1186/1743-422X-8-554}

Cite this article as: Lam et al:: Apoptosis, cytokine and chemokine induction by non-structural 1 (NS1) proteins encoded by different influenza subtypes. Virology Journal 2011 8:554.

\section{Submit your next manuscript to BioMed Central and take full advantage of:}

- Convenient online submission

- Thorough peer review

- No space constraints or color figure charges

- Immediate publication on acceptance

- Inclusion in PubMed, CAS, Scopus and Google Scholar

- Research which is freely available for redistribution

Submit your manuscript at www.biomedcentral.com/submit
C Biomed Central 